\title{
AKTIVITAS ANTIOKSIDATIF DAN ANTI-GLIKASI EKSTRAK FENOLIK BEBAS DAN FENOLIK TERIKAT DARI TONGKOL JAGUNG
}

\author{
Edi Suryanto ${ }^{1}$ dan Mercy I.R. Taroreh ${ }^{2}$ \\ ${ }^{1}$ Program Studi Kimia Fakultas Matematika dan Ilmu Pengetahuan Alam Universitas Sam Ratulangi Manado \\ ${ }^{2}$ Program Studi Teknologi Pangan Fakultas Pertanian Universitas Sam Ratulangi Manado
}

\begin{abstract}
ABSTRAK
Penelitian ini bertujuan untuk menentukan aktivitas antioksidan dan anti glikasi ekstraks fenolik bebas dan ekstrak fenolik terikat dari tongkol jagung. Tongkol jagung diekstraksi secara sekuensial berbantu ultrasonikasi dengan pelarut etanol dan aseton selama 60 menit yang untuk mendapatkan ekstrak fenolik bebas. Residu dari ekstraksi fenolik bebas dihidrolisis dengan $\mathrm{NaOH} 2 \mathrm{M}$ dan dinetralkan serta diekstraksi dengan etil asetat untuk mendapatkan ekstrak fenolik terikat. Ketiga ekstrak tersebut dilakukan analisis kandungan total fenolik dan pengujian aktivitas antioksidan dan anti glikasi. Kandungan total fenolik ekstrak ekstrak fenolik terikat (EFT), ekstrak fenolik bebas aseton (EFBA) dan ekstrak fenolik bebas etanol (EFBE) berturut-turut adalah 288,39; 100,32 dan 92,95 $\mu \mathrm{g} / \mathrm{mL}$ yang dinyatakan sebagai ekuivalen asam galat. Ekstrak EFT menunjukkan aktivitas penangkalan radikal bebas DPPH dan total antioksidan lebih tinggi daripada ekstrak EFBA dan ekstrak EFBE. Sejalan dengan itu, aktivitas anti glikasi dari EFT, EFBA dan EFBE berturut-turut adalah 61,93; 64,42 dan $66,31 \%$. Hasil penelitian ini menyimpulkan bahwa ekstrak EFT dari tongkol jagung mengandung senyawa yang memilki sifat antioksidan dan berpotensi sebagai anti glikasi.
\end{abstract}

Kata kunci: Tongkol jagung, ekstraksi sekuensial, alkalin, antioksidan, antiglikasi

\section{ABSTRACT}

This objective of this research was to determine the antioxidant activity and inhibition of AGEs formation of free phenolic and bound phenolic extract from corn cobs. Corn cobs were extracted sequentially assisted by ultrasonication with ethanol and acetone solvents for 60 minutes to obtain free phenolic extract. The residue from free phenolic extraction was hydrolyzed with $2 \mathrm{M} \mathrm{NaOH}$ and neutralized and extracted with ethyl acetate to obtain bound phenolic extract. The three extracts were analyzed for total phenolic content and evaluated for antioxidant activity and inhibitory activity of AGEs formation. The total phenolic content of bound phenolic extract (EFT), acetone-free phenolic extract (EFBA) and ethanol-free phenolic extract (EFBE) were 288,39; 100,32 and 92,95 $\mu \mathrm{g} / \mathrm{mL}$ expressed as gallic acid equivalents, respectively. EFT extract showed higher DPPH free radical scavenging activity and total antioxidants more than EFBA extract and EFBE extract. Anti-glication of EFT, EFBA and EFBE were 61,$93 ; 64,42$ dan $66,31 \%$, respectively. These result concluded that the EFT extract from corn cobs contains compounds having antioxidant properties and potential as anti-glication.

Keyword: Corcob, sekuential extraction, alkalin, antioxidant, anti-glication

\section{PENDAHULUAN}

Tongkol jagung merupakan bagian terbesar dari buah jagung, sehingga produksi jagung pipilan dalam jumlah yang besar dapat menghasilkan limbah tongkol jagung yang cukup banyak. Penggunaan biomassa lignoselulosa seperti tongkol jagung sebagai bahan baku biomassa yang menawarkan berbagai kemungkinan untuk produksi serat pangan dan fitokimia yang bermanfaat untuk kesehatan. Tongkol jagung merupakan limbah utama pertanian dan berlimpah dalam komponen hemiselulosa, selulosa, lignin, komposisi mineral dan komposisi fitokimia (Abubakar

\footnotetext{
Korespondensi:

Telepon: +62 853-9856-6170

Email: edi7suryanto@gmail.com

DOI: https://doi.org/10.35799/cp.13.2.2020.31393
}

dkk., 2016; Suryanto dkk., 2017). Semua komponen tersebut mempunyai aplikasi yang luas yang dapat dimanfaatkan untuk keperluan di bidang pangan, medikal, industri kimia dan farmasi.

Serat pangan telah terbukti memiliki peran penting dalam pencegahan resiko karsinogenesis, aterosklerosis, serta mengendalikan pelepasan glukosa dengan waktu tertentu sehingga membantu dalam pengelolaan diabetes mellitus dan obesitas yang tepat (Trinidad dkk., 2001). Beberapa studi melaporkan bahwa tongkol jagung mengandung senyawa fenolik, flavonoid, tannin dan memiliki aktivitas antioksidan, singlet oxygen quenching 
dan bahan aktif tabir surya (Suryanto dkk., 2013; Suryanto dkk., 2017). Senyawa fenolik dapat mencegah resiko kanker, penyakit jantung koroner, stroke, artherosclerosis, ospteoporosis, inflamasi dan penyakit neurodegeneratif yang berhubungan dengan stress oksidatif (Ames \& Shigenaga, 1993; Shahidi \& Naczk, 1995; Halliwel \& Gutteridge, 2001). Stres oksidatif dapat menyebabkan pembentukan AGEs (Advanced Glycation End-Products) yang dapat memicu patogenis penyakit diabetes, Alzheimer, stroke, jantung coroner, osteoporosis dan kanker (Ganeshan dkk., 2015). Beberapa peneliti melaporkan bahwa senyawa fenolik seperti vitexin, isovitexin, gracinol dan senyawa flavonoid kaempferol, luteolin, naringenin, kuesertin, rutin, epikatekin galat dan epigalokatekin galat memiliki kemampuan untuk antioksidan dan anti glikasi (Peng dkk. 2008; Wu \& Yen, 2005; Yamaguchi dkk., 2000).

Secara umum, senyawa fenolik terdapat di dalam bentuk bebas maupun terikat di dalam dinding sel tumbuhan dan senyawa fenolik bebas tersebut hanya dapat diekstraksi dengan pelarut. Sebaliknya, senyawa fenolik terikat merupakan senyawa kovalen yang terikat ke matriks tanaman dan tidak dapat diekstraksi dalam air atau campuran pelarut air dan organik (Perez-Jimenez \& Torres, 2011). Meskipun kandungan total fenolik dan aktivitas antioksidan tongkol jagung telah dilaporkan sebelumnya tetapi penelitian tersebut hanya mempertimbangkan pelarut yang dapat diekstraksi senyawa fenolik bebas yang terdapat di dalam tongkol jagung (Suryanto dkk., 2013; Suryanto dkk., 2017; Suryanto dkk., 2018; Suryanto dkk., 2020). Atas dasar ini, kandungan fenolik dan aktivitas antioksidan dari tanaman pangan maupun bukan pangan kurang menjadi perhatian dan pertimbangkan padahal sebagian besar, fraksi terikat ini merupakan kumpulan senyawa fitokimia yang mungkin memiliki bioaktivitas tinggi. Namum, belum ada laporan tentang bebas dan fenolik terikat dan terbatasnya literatur terhadap fenolik terikat serta aktivitas antioksidan dari tongkol jagung. Tujuan penelitian ini adalah untuk menentukan kandungan fitokimia yang terdapat pada ekstrak fenolik bebas dan fenolik terikat serta aktivitas antioksidan dan antiglikasi di dalam tepung serat pangan tak larut dari tongkol jagung.

\section{BAHAN DAN METODE}

\section{Bahan dan alat}

Bahan dan alat yang dipakai dalam penelitian ini adalah tongkol jagung jenis Manado kuning diperoleh dari kebun masyarakat di daeraha Tompaso, Minahasa. Beberapa bahan kimia yang digunakan dalam penelitian ini adalah etanol, aseton, etil asetat, natrium karbonat, Folin-Ciocalteu, bovine serum albumin (BSA) dan natrium azida diperoleh dari Merck (Darmstadt, Germany). 1,1-difenil-2pikrilhidrazil (DPPH), diperoleh dari Sigma Chemical Co. (St. Lois, MO). Asam galat, ferozine, ferric-2,4,6-tripirydil-s-triazine dari Aldrich Chemical Co. (Milwaukee, Wisconsin). Peralatan yang digunakan adalah oven, blender (Philips HR 2116, Indonesia), rotary evaporator (Buchi R-100, Switzerland), vortex mixer, shaker, penangas air, seperangkat alat Soxhlet, desikator, mikropipet, Spektrofotometer UVVIS (Shimadzu 1800, Jepan), alat milling (Fomac tipe FCT-Z200 frekuensi 50-60 Hz.

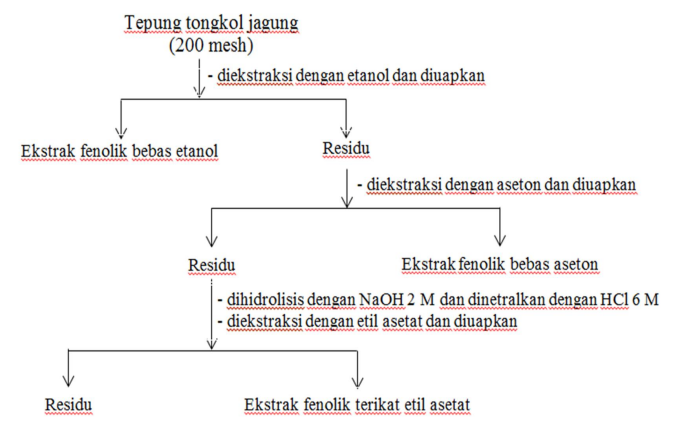

Gambar 1. Diagram alir ekstraksi sekuensial ekstrak fenolik bebas dan fenolik terikat dari tongkol jagung

\section{Preparasi dan pelarut ekstraksi}

Tongkol jagung jenis Manado Kuning yang telah kering digiling menggunakan blender dan dihaluskan dengan alat penggiling (Fomac FCT-Z200, frekuensi 40-60 $\mathrm{Hz}$ ) untuk mendapatkan tepung tongkol jagung yang lolos ayakan 200 mesh. Sebanyak $5 \mathrm{~g}$ tepung tongkol jagung (200 mesh) diekstraksi secara sekuensial dengan etanol $80 \%$ dan aseton $80 \%$ dan diaduk selama 60 menit untuk menghasilkan ekstrak fenolik bebas etanol (EFBE) dan ekstrak fenolik bebas sekuensial aseton (EFBA). Selanjutnya residu dari EFBA diperlakukan dengan $\mathrm{NaOH} 2$ $\mathrm{M}$, diaduk selama 60 menit dan dinetralkan dengan asam klorida $6 \mathrm{M}$ selanjutnya diekstraksi dengan $5 \times 20 \mathrm{~mL}$ etil asetat dan diuapkan sampai pekat untuk mendapatkan ekstrak fenolik terikat 
(EFT). Diagram alir ekstraksi sekuensial tongkol jagung ditunjukkan pada Gambar 1.

\section{Penentuan kandungan total fenolik}

Kandungan total fenolik dari ekstrak EFBE, EFBA dan EFT dari tongkol jagung ditentukan dengan metode Jeong dkk., (2004). Sampel masing-masing ekstrak tersebut sebanyak $1 \mathrm{~mL}$ ditambahkan dengan $1 \mathrm{~mL}$ reagen Folin-Ciocalteu (50\%) dalam tabung reaksi dan kemudian campuran ini divortex selama 3 menit. Setelah interval waktu 3 menit, $2 \mathrm{~mL}$ larutan $\mathrm{Na}_{2} \mathrm{CO}_{3} \quad 2 \%$ ditambahkan. Selanjutnya campuran disimpan dalam ruang gelap selama 30 menit. Absorbansi sampel dibaca dengan spektrofotometer pada $\lambda 750 \mathrm{~nm}$. Hasilnya dinyatakan sebagai ekuivalen asam galat dalam $\mu \mathrm{g} / \mathrm{mL}$ ekstrak. Kurva kalibrasi dipersiapkan pada cara yang sama menggunakan asam galat sebagai standar.

\section{Penentuan penangkal radikal bebas DPPH}

Penentuan aktivitas penangkal (scavenger) radikal bebas dari ekstrak EFBE, EFBA dan EFT diukur dengan metode Li dkk. (2012) yang sedikit dimodifikasi. Sebanyak 2 $\mathrm{mL}$ larutan 1,1-difenil-2-pikrilhidrazil (DPPH) $0,2 \mathrm{mM}$ dalam etanol ditambahkan $0,5 \mathrm{~mL}$ ekstrak tepung komposit. Tingkat berkurangnya warna dari larutan menunjukkan efesiensi penangkap radikal. Lima menit terakhir dari 30 menit, absorbansi diukur dengan spektrofotometer pada $\lambda 517 \mathrm{~nm}$. Aktivitas penangkal radikal bebas dihitung sebagai persentase berkurangnya warna DPPH dengan menggunakan persamaan:

$$
1-\frac{\text { absorbansisampel }}{\text { absorbansikontrol }} \times 100 \%
$$

\section{Penentuan total antioksidan}

Penentuan total antioksidan ditentukan menurut metode ferric reducing ability of plasma, FRAP (Szydlowska-Czerniak dkk., 2008). Pengukuran dilakukan dengan mengambil $0,1 \mathrm{~mL}$ ekstrak EFBE, EFBA dan EFT yang dilarutkan dalam etanol dicampurkan dengan $3 \mathrm{~mL}$ reagen FRAP dalam keadaan segar. Kemudian campuran dikocok dengan alat vortex dan setelah itu, segera dilakukan pengukuran absorbansinya pada panjang gelombang $593 \mathrm{~nm}$. Reagen FRAP selalu dipersiapkan dalam keadaan segar dengan mencampurkan 2,5 mL, $10 \mathrm{mM}$ larutan 2,4,6- tripiridil-s-triazina (TPTZ) dalam $40 \mathrm{mM} \mathrm{HCl}$ mM dengan 2,5 mL, $20 \mathrm{mM}$ larutan $\mathrm{FeCl}_{3} 6 \mathrm{H}_{2} \mathrm{O}$ dan 2,5 mL, 0,3 M buffer asetat pada $\mathrm{pH}$ 3,6. Kandungan total antioksidan dinyatakan sebagai ekuivalen $\mathrm{Fe}^{3+}$ menjadi $\mathrm{Fe}^{2+}$ dalam $\mu \mathrm{mol} / \mathrm{L}$ ekstrak. Untuk membuat kurva standar dipersiapkan pada cara yang sama menggunakan larutan $\mathrm{FeSO}_{4}$ dengan konsentrasi antara 100$1000 \mu \mathrm{mol} / \mathrm{L}$.

\section{Penentuaan kandungan karbonil protein}

Gugus karbonil di dalam BSA terglikasi merupakan suatu penanda untuk kerusakan oksidatif protein yang dievaluasi menurut Adisakwattana dkk. (2012) dan Mesquita dkk. (2014) dengan sedikit modifikasi. Secara singkat, BSA $(15 \mathrm{mg} / \mathrm{mL})$ inkubasi dengan $1 \mathrm{M}$ glukosa di dalam bufer fosfat $\mathrm{pH} 7$ yang mengandung $0,02 \%$ natrium azida dalam gelap pada $37{ }^{\circ} \mathrm{C}$ selama 14 hari. Sebelum inkubasi, sebanyak $1 \mathrm{mg} / \mathrm{mL}$ masing-masing ekstrak EFBE, EFBA dan EFT ditambahkan ke dalam campuran tersebut dan bufer fosfat $\mathrm{pH} 7$ sebagai kontrol. Pembentukan BSA terglikasi diukur dengan metode 2,4-dinitrofenilhidrazin (DNPH) alkalin, sebanyak $400 \mu \mathrm{L}$ DNPH $(10 \mathrm{mM}, 2,5 \mathrm{M}$ $\mathrm{HCl})$ ditambahkan $400 \mu \mathrm{L}$ larutan BSA dalam tabung reaksi dan kemudian campuran ini divortex dan diinkubasi selama 10 menit setelah itu ditambahkan $400 \quad \mu \mathrm{L} \quad \mathrm{NaOH} \quad\left(\begin{array}{lll}6 & \mathrm{M}\end{array}\right)$. Absorbansi diukur dengan spektrofotometer pada $\lambda 450 \mathrm{~nm}$ setelah 10 menit inkubasi pada suhu kamar. Persentase penghambatan gugus karbonil dalam glikasi BSA menggunakan rumus:

$\%$ Inhibisi glikasi protein $=[1-($ absorbansi sampel/absorbansi kontrol )] $\times 100 \%$

\section{Spektra UV}

Analisis spektra ultraviolet (UV) untuk masing-masing ekstrak etanol dan fraksi pelarut petroleum eter, etil asetat, butanol, dan aquadest diukur dengan cara absorpsi UV pada panjang gelombang 200-400 nm menggunakan spektrofotometer (Shimadzu 1800) dalam pelarut etanol.

\section{Analisis statistik}

Semua data eksperimen dilakukan dua kali ulangan dan hasilnya dinyatakan sebagai rataan \pm SD. Apabila perlakuan berpengaruh nyata, pengujian beda rataan perlakuan dilanjutkan dengan uji beda rataan dengan DMRT (Duncan's multiple range test). Analisis 
dilakukan menggunakan software SPSS versi 18.

\section{HASIL DAN PEMBAHASAN}

\section{Ekstraksi dan kandungan fenolik}

Ekstraksi dilakukan secara sekuensial (berurutan) dengan pelarut etanol dan aseton untuk memisahkan senyawa-senyawa fenolik bebas dan terikat dengan tingkat polaritasnya. Ekstraksi menggunakan etanol dapat melarutkan senyawa polar dan pelarut aseton melarutkan senyawa-senyawa semipolar. Tujuan kedua pelarut ini adalah untuk mencari komponenkomponen yang dapat berperan sebagai antioksidan dan anti glikasi yang terdapat di dalam tongkol jagung dengan tingkat polaritas. Tabel 1. menunjukkan hasil ekstraksi dan kandungan total fenolik dari tiga jenis ekstrak tongkol jagung. Hasil ekstraksi pelarut tertinggi diperoleh dari ekstrak fenolik bebas aseton (EFBA) sebesar 7,99\% dan terendah terdapat pada ekstrak fenolik terikat (EFT) sebesar $1,95 \%$. Dari hasil ini dapat dilihat bahwa jenis pelarut yang digunakan berpengaruh pada rendemen ekstraksi. Dari ketiga jenis ekstrak yang diteliti EFT menunjukkan penurunan rendemen dibandingkan dengan EFBE dan EFBA. Hal ini kemungkinan disebabkan senyawa yang terdapat dalam EFT lebih banyak bersifat semipolar daripada polar sehingga aseton yang bersifat semipolar memberikan rendemen yang lebih banyak. Komponen yang diduga berkontribusi terhadap ekstrak aseton adalah selain senyawa fenolik bebas dan juga komponen lain seperti protein, lemak dan karbohidrat.

Tabel 2. Rendemen ekstraksi dan kandungan total fenolik ekstrak fenolik bebas dan terikat dari tongkol jagung

\begin{tabular}{lcc}
\hline \multicolumn{1}{c}{ Sampel } & $\begin{array}{c}\text { Rendemen } \\
(\%)\end{array}$ & $\begin{array}{c}\text { Kandungan } \\
\text { total fenolik } \\
(\mu \mathrm{g} / \mathrm{mL})\end{array}$ \\
\hline $\begin{array}{l}\text { Ekstrak fenolik } \\
\text { bebas etanol } \\
\text { (EFBE) }\end{array}$ & $7,14 \pm 1,75^{\mathrm{a}}$ & $92,95 \pm 4,56^{\mathrm{a}}$ \\
$\begin{array}{l}\text { Ekstrak fenolik } \\
\text { bebas aseton } \\
\text { (EFBA) }\end{array}$ & $7,99 \pm 2,41^{\mathrm{b}}$ & $100,32 \pm 7,33^{\mathrm{b}}$ \\
$\begin{array}{l}\text { Ekstrak fenolik } \\
\text { terikat (EFT) }\end{array}$ & $1,95 \pm 0,33^{\mathrm{c}}$ & $288,39 \pm 2,23^{\mathrm{c}}$ \\
\hline \multicolumn{2}{c}{ Hasil analisis kandungan total fenolik } \\
\multicolumn{2}{l}{ dari ketiga ekstrak fenolik bebas dan terikat }
\end{tabular}

dapat dilihat pada Tabel 2. Seperti yang ditunjukkan pada Tabel 1, kandungan total fenolik tertinggi diperoleh dari ekstrak sampel EFT $(288,39 \mu \mathrm{g} / \mathrm{mL})$ diikuti dengan EFBA $(100,32 \mu \mathrm{g} / \mathrm{mL})$ dan EFBE $(92,95 \mu \mathrm{g} / \mathrm{mL})$. Dari hasil ini menunjukkan bahwa senyawa fenolik terikat mempunyai nilai kandungan total fenolik yang cukup tinggi, hal tersebut diduga bahwa pada tepung tongkol jagung dari sisa penyaringan selama diekstraksi menggunakan basa masih mengandung bahan aktif terutama senyawa fenolik yang terkandung dalam residu tersebut.

Beberapa peneliti melaporkan bahwa kandungan total fenolik di dalam ekstrak fenolik terikat lebih tinggi dibandingkan dengan ekstrak fenolik bebas dari biji jagung dan kulit anggur, gandum, oat, beras dan kulit jambu (Parra dkk., 2007; Woworuntu dkk., 2018; Karepu dkk., 2020; Saura-Calixto, 1998; Jimenez-Escrig dkk., 2001). Sebaliknya beberapa penelitian lain juga melaporkan bahwa ekstrak fenolik bebas di dalam daging buah pala, ampas sagu baruk dan kulit jeruk lebih tinggi dibandingkan dengan ekstrak fenolik terikat (Nova dkk., 2020; Dareda dkk., 2020; Tao dkk., 2014). Hal ini mungkin disebabkan perbedaan dari bahan tumbuhan ketika diekstraksi dengan pelarut. Secara umum analisis kandungan fitokimia biasanya dalam bentuk ikatan bebas, larut dan tak larut sedang bahan tumbuhan kebanyakan adalah bentuk ikatan tak larut karena terikat oleh dinding sel. Hal ini berarti bahwa dalam proses ekstraksi fenolik bebas tidak banyak senyawa fenolik yang larut dan mungkin disebabkan pengaruh oleh pelarut atau adanya co-solvent sehingga menyebabkan hanya sedikit senyawa fenolik yang larut di dalamnya. Proses ekstraksi untuk senyawa fenolik bebas maupun terikat mempengaruhi pemilihan pelarut terhadap kandungan dari senyawa fenolik (Adom \& Liu, 2002). Tujuan penambahan pelarut etil asetat pada ekstraksi fenolik terikat karena etil asetat dapat melarutkan senyawa fenolik yang lebih banyak sehingga menunjukkan sebagian besar senyawa fenolik yang merupakan senyawa bersifat semipolar. Suryanto dkk. (2017), menyatakan bahwa pelarut etil asetat sangat cocok untuk mengekstraksi senyawa fenolik ketika dilakukan proses ekstraksi dengan cara partisi msupun cara hidrolisis untuk mendapatkan ekstraks fenolik bebas dan ekstraks fenolik terikat tetapi kurang baik untuk melarutkan senyawa fenolik di dalam tumbuah 
secara langsung karena tingkat polaritasnya dapat mempengaruhi kelarutan senyawa fenolik.

\section{Aktivitas antioksidan}

Pengujian dengan radikal 1,1-difenil-2picrylhidrazy (DPPH) digunakan untuk menentukan aktivitas penangkal radikal bebas dari ekstrak tanaman maupun senyawa murni. Radikal DPPH adalah radikal bebas stabil yang dapat larut dalam metanol atau etanol serta menunjukkan karakteristik pada panjang gelombang 515-517 nm (Suryanto dkk. 2017). Aktivitas antioksidan dievaluasi menggunakan berbagai pengujian secara in vitro yang meliputi aktivitas penangkal radikal bebas DPPH dan total antioksidan dengan metode FRAP. Hasil pengujian aktivitas penangkal radikal bebas dan total antioksidan dari ekstrak fenolik bebas etanol (EFBE), ekstrak fenolik bebas aseton (EFBA) dan ekstrak fenolik terikat (EFT) dapat dilihat pada Tabel 3.

Secara umum semua ekstrak menunjukkan aktivitas penangkal radikal bebas DPPH melebihi 50\%, hal ini berarti bahwa ekstrak fenolik bebas dan fenolik terikat dapat menghambat radikal bebas seperti fungsi antioksidan primer. Antioksidan primer dapat menangkal radikal bebas melalui pemberian hidrogen kepada radikal bebas DPPH yang berwarna ungu dan akan berubah menjadi non radikal yang berwarna kuning. Semakin berkurangnya warna ungu menunjukkan bahwa kemampuan antioksidan tersebut untuk menangkal radikal bebas DPPH semakin kuat (Suryanto, 2018).

Tabel 3. Aktivitas penangkal radikal bebas DPPH dan total antioksidan ekstrak fenolik bebas dan terikat dari tongkol jagung

\begin{tabular}{lcc}
\hline Sampel & $\begin{array}{c}\text { Aktivitas penangkal } \\
\text { radikal bebas DPPH } \\
(\%)\end{array}$ & $\begin{array}{c}\text { Total } \\
\text { antioksidan } \\
(\mu \mathrm{mol} / 100 \mathrm{~g})\end{array}$ \\
\hline EFBA & $80,27 \pm 1,11^{\mathrm{a}}$ & $297,01 \pm 0,22^{\mathrm{a}}$ \\
EFBE & $83,77 \pm 0,67^{\mathrm{b}}$ & $340,15 \pm 2,87^{\mathrm{b}}$ \\
EFT & $91,61 \pm 0,56^{\mathrm{c}}$ & $868,34 \pm 0,99^{\mathrm{c}}$ \\
\hline
\end{tabular}

Hasil analisis penangkal radikal bebas DPPH terhadap ketiga jenis ekstrak EFBA, EFBE dan EFT menunjukkan bahwa persentase penangkal radikal bebas ekstrak EFT $(91,61 \%)$ memiliki aktivitas penangkal radikal bebas DPPH yang paling tinggi daripada EFBE $(83,77 \%)$ dan EFBA $(80,27 \%)$. Dari data ini dapat digambarkan bahwa senyawa antioksidan dalam tongkol jagung selain dipengaruhi oleh polaritas pelarut tetapi juga perlakuan hidrolisis selama proses ekstraksi. Fenolik terikat mempunyai aktivitas paling tinggi, hal ini mungkin disebabkan residu dari ekstrak fenolik bebas yang dihidrolisis dengan basa dan asam masih mengandung fitokimia antioksidan di dalam tongkol jagung. Beberapa penelitian melaporkan bahwa proses hidrolisis asam-basa dari residu hasil ekstrak fenolik bebas dan diekstraksi dengan etil asetat dapat meningkatkan kandungan total fenolik dan aktivias antioksidan yang terkandung dalam residu tersebut (Parra dkk., 2007; Dvořáková dkk., 2008; Yang dkk. 2014; Su dkk. 2014; Yang dkk. 2018).

Pengujian dengan metode ferric reducing ability of plasma (FRAP) merupakan kemampuan antioksidan untuk mereduksi ion $\mathrm{Fe}^{3+}$ menjadi $\mathrm{Fe}^{2+}$. Intensitas warna biru dari kompleks Fe(III)-TPTZ (ferric-2,4,6-tripirydil$s$-triazine) dapat diubah menjadi Fe(II)-TPTZ (ferrous-2,4,6-tripirydils-triazine) pada $\mathrm{pH}$ rendah pada panjang gelombang $593 \mathrm{~nm}$ (Benzie dan Strain, 1996). Tabel 3 memperlihatkan kapasitas total antioksidan dari ketiga jenis ekstrak berbeda secara signifikan $(p<0,05)$ dari satu ke lainnya. Sampel EFT memiliki total antioksidan terbesar sedangkan EFBA dan EFBE memiliki kapasitas paling rendah di antara semua sampel yang dianalisis.

Total antioksidan yang rendah pada ekstrak fenolik bebas (EFBE dan EFBA) berkaitan dengan rendahnya kontribusi senyawa fenolik dalam kedua ekstrak tersebut daripada ekstrak fenolik terikat (EFT). Kandungan total fenolik tinggi menunjukkan tinggi pula kapasitas total antioksidan dan aktivitas penangkal radikal bebas dari ekstrak nenas, pisang dan jambu (Althoman dkk., 2009). Selain itu, peningkatan kapasitas total antioksidan ini disebabkan oleh perlakuan hidrolisis dengan alkalin yang mengubah atau merusak matriks serat, sehingga menyebabkan beberapa fenolik terikat menjadi terlepas dari matrik dinding sel tanaman. Ada beberapa laporan lain yang menyajikan fenomena serupa yang mengungkapkan bahwa total antioksidan dengan metode FRAP meningkat setelah perlakuan hidrolisis (Tao et al. 2014; Yang dkk. 2014; Yang dkk., 2018). Hasil penelitian ini mengindikasikan bahwa pengujian kapasitas total antioksidan dan penangkal radikal bebas DPPH menunjukkan kecendrungan yang sama untuk ekstrak fenolik bebas etanol (EFBE) maupun ekstrak fenolik 
bebas aseton (EFBA) serta ekstrak fenolik terikat (EFT). Beberapa penelitian menunjukkan bahwa metode dengan pengujian FRAP dan DPPH memiliki kecendrung hasil yang sama dengan kandungan total fenolik dari ekstrak tanaman pangan (Gill dkk., 2000; Alothman dkk., 2009).

\section{Aktivitas penghambatan pembentukan AGEs}

Aktivitas penghambat pembentukan AGEs (advanced glycation end-products) secara in vitro dengan menggunakan model BSAglukosa untuk pengujian efek berbagai senyawa terhadap proses glikasi non-enzimatik. Dalam proses glikasi nonenzimatis diawali reaksi glukosa dengan gugus amina untuk membentuk basa Schiff yang tidak stabil melalui penataan ulang menjadi produk Amadori. Basa Schiff sangat rentan terhadap generasi oksidasi dan radikal bebas yang selanjutnya mengarah pada pembentukan spesies karbonil reaktif (RCS) yang dapat bereaksi dengan gugus amino, sulfidril dan guanidin dari protein intraseluler dan ekstraseluler menghasilkan formasi dari AGEs (Rahbar dkk., 2000; Wu \& Yen, 2008).

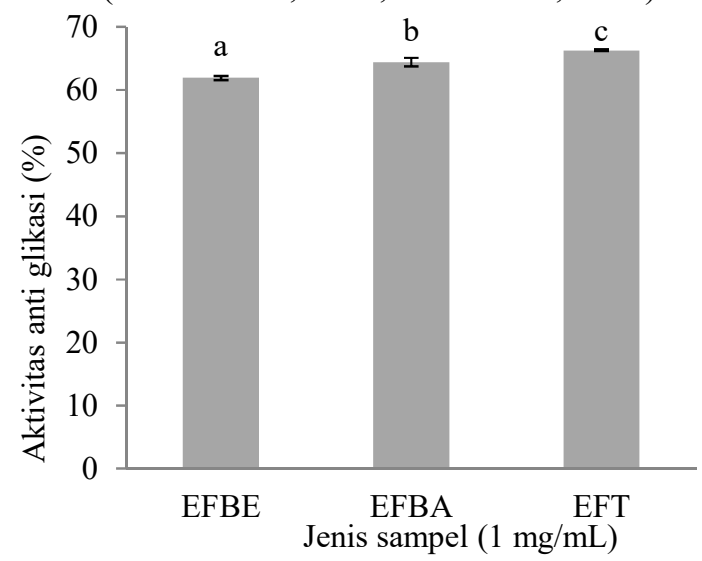

Gambar 2. Aktivitas penghambatan pembentukan AGEs dari ekstrak fenolik bebas dan terikat dari tongkol jagung.

Gambar 2. memperlihatkan efek anti glikasi dari ekstrak fenolik bebas etanol (EFBE), ekstrak fenolik bebas aseton (EFBA) dan ekstrak fenolik terikat (EFT) terhadap pembentukan AGEs dalam sistem model. Semua ekstrak menunjukkan efek aktivitas yang signifikan pada konsentrasi $1 \mathrm{mg} / \mathrm{mL}$ dengan penghambatan sebesar 66,31\% untuk EFT, $64,42 \%$ untuk EFBA dan $61,93 \%$ untuk EFBE. Berbagai antioksidan fenolik dari ekstrak tumbuhan telah ditemukan untuk menghambat pembentukan AGEs dan penghambatan pembentukan radikal bebas dalam proses glikasi dan penghambatan selanjutnya dari modifikasi protein telah dianggap sebagai mekanisme utama untuk menengahi aktivitas anti-glikasi (Peng dkk., 2008). Hasil ini mengindikasikan bahwa ekstrak EFT memiliki efek penghambatan pembentukaan AGEs sejalan dengan kandungan fenolik dan aktivitas antioksidan tertinggi pula.

Gambar 2 menunjukkan bahwa sampel EFT memiliki aktivitas penghambat pembentukan AGEs yang tertinggi diikuti dengan EFBE dan EFBA. Efek penghambatan ini mungkin disebabkan adanya kontribusi sebagian besar jumlah antioksidan fenolik yang dikandungnya. Hal itu membuktikan bahwa radikal bebas terlibat dalam pembentukan AGEs dan diperkirakan bahwa antioksidan fenolik dapat menghambat pembentukan AGEs. Produk glikasi dapat dioksidasi oleh ROS sehingga membentuk AGEs. Akumulasi AGEs pada protein disertai dengan pencoklatan, peningkatan flouresensi dan cross-lingking. Beberapa penelitian melaporkan bahwa berbagai antioksidan fenolik dari ekstrak tumbuhan telah ditemukan dapat menghambatan pembentukan AGEs dan penghambatan generasi radikal bebas di dalam proses glikasi (Yamaguchi dkk., 2000; Lunceford \& Gugliucci, 2005; Peng dkk. 2008; Wu \&Yen, 2008). Menurut Wu \& Yen, 2005), usul mekanisme yang mungkin dalam penghambatan glikasi protein oleh senyawa antioksidan adalah penghambatan pembentukan radikal bebas yang berasal dari proses glikasi dan penghambatan modifikasi protein yang dianggap salah satu mekanismenya efek antiglikasi. Data ini didukung oleh beberapa penelitian yang menunjukkan bahwa antioksidan atau nutrisi seperti vitamin B1 (tiamin pirofosfat), vitamin B6 (piridoksamin), vitamin C, vitamin E, niacinamide, karnosin, dan natrium selenit dapat menghambat secara in vivo dan in vitro pembentukan AGEs (Booth dkk., 1996; Vinson \& Howard, 1996; Krone \& Ely, 2004).

\section{Spektra UV}

Gambar 3. menunjukkan spektra absorpsi dari ekstrak EFBE, EFBA dan EFT diukur dalam pelarut etanol dengan daerah panjang gelombang 200-400 nm untuk senyawa fenolik. Karakteristik komponen fenolik dalam ekstrak EFBE, EFBA dan EFT diidentifikasi dengan spektrofotometri ultraviolet (UV). Hasil penelitian membuktikan bahwa spektrum UV 
ekstrak EFBE, EFBA dan EFT menunjukkan kemampuan untuk mengekstraksi komponen fenolik. Seperti ditunjukkan Gambar 3 dalam spektra dalam ketiga sangat tergantung terhadap polaritas dari pelarut pengekstraksi. Ekstrak EFBE, EFBA dan EFT menunjukkan absorbansi maksimum berturut-turut adalah 312,316 dan $312 \mathrm{~nm}$. Hasil ini membuktikan bahwa spektra UV dari ketiga ekstrak dari pelarut etanol, aseton dan etil asetat menunjukkan kemampuan untuk pengekstrak komponen fenolik.

Spektrum UV ekstrak EFT merupakan ekstrak fenolik terikat yang lebih efektif untuk memperoleh senyawa fenolik di dalam sampel tongkol jagung. Seperti yang ditunjukkan pada Gambar 3 dapat dilihat bahwa EFT memiliki dua puncak serapan utama pada daerah $312 \mathrm{~nm}$ dan $297 \mathrm{~nm}$ dan memberikan nilai absorbansi pada daerah 2,79 dan 2,66. Kedua puncak ini biasanya disebut sebagai Band I (312 nm) dan band II (297 nm). Ini dapat disebabkan kehadiran sejumlah besar senyawa fenolik terutama golongan asam fenolat yang lebih mudah dihidrolisis dengan alkalin.

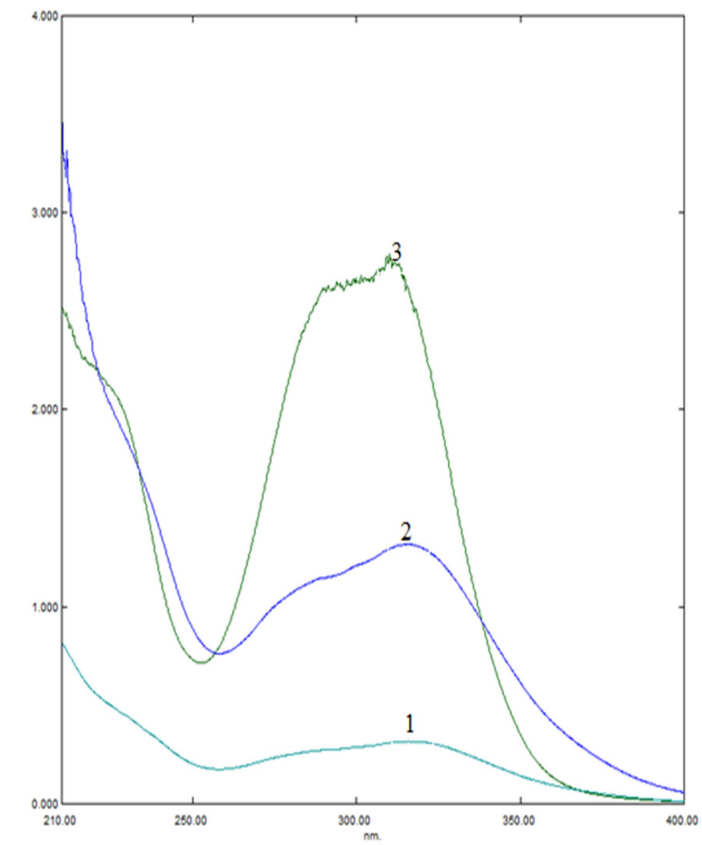

Gambar 3. Spektra absorbansi dari $50 \mu \mathrm{g} / \mathrm{mL}$. 1. EFBE, 2. EFBA dan 3.EFT

Metode spektrofotometer bisa digunakan untuk identifikasi asam fenolat dan secara umum memiliki panjang gelombang antara rentangan 220 sampai $320 \mathrm{~nm}$ (Mabry dkk. 1970; Macheix dkk. 1990). Asam fenolat merupakan salah satu jenis metabolit sekunder yang banyak ditemukan dalam lignoselulosa tanaman pangan maupun tanaman obat yang berada dalam keadaan bebas, esterifikasi, glikosida dan bentuk ikatan tak larut. Huang et al. (2011) mendapatkan konsentrasi tinggi asam ferulat dari limbah pertanian lignoselulosa seperti kulit padi, kulit gandum dan tongkol jagung dengan memanfaatkan enzim extracellular esterase dan xylanase dari Thermobifida fusca NTU22. Tongkol jagung menunjukkan rendemen terbaik untuk memperoleh asam ferulat. Beberapa peneliti melaporkan bahwa lignoselulosa dari jerami gandum dan ampas tebu yang diekstraksi dengan alkalin ( $\mathrm{KOH} 0,5 \mathrm{M}$ atau $\mathrm{NaOH} 1 \mathrm{M}$ ) menemukan asam fenolat seperti asam $p$ hidroksibenzoat, $p$-hidroksisibenzaldehid, asam vanilat, asam siringat, vanillin, siringaldehid, asam p-koumarat dan asam ferulat (Sun \& Tomkison, 2002; Xu dkk., 2006). Karamaæ dkk. (2005) melaporkan bahwa asam fenolat seperti asam siringat menunjukkan aktivitas penagkal radikal bebas paling kuat daripada asam ferulat, asam vanilat, asam p-koumarat dan $p$ hidroksibenzoat.

\section{KESIMPULAN}

Penelitian ini menunjukkan bahwa kandungan fenolik di dalam ekstrak fenolik terikat (EFT) lebih tinggi dan ekstrak tersebut memiliki aktivitas antioksidan yang kuat dibandingkan dengan ekstrak fenolik bebas aseton (EFBA) dan ekstrak fenolik bebas etanol (EFBE). Hasil penelitian ini juga menunjukkan bahwa EFT memiliki kemampuan sebagai antiglikasi yang lebih tinggi daripada EFBA dan EFBE. Oleh karena itu, hasil penelitian menyimpulkan bahwa kandungan senyawa fenolik di dalam ekstrak bebas maupun terikat dipengaruhi oleh pemilihan pelarut ekstraksi dan memiliki kemampuan antioksidan dan antiglikasi yang baik.

\section{UCAPAN TERIMA KASIH}

Penulis mengucapkan terima kasih kepada Deputi Bidang Penguatan Riset dan Pengembangan: Riset Dasar Unggulan Perguruan Tinggi (RDUPT) Tahun 2020. Kementerian Riset dan Teknologi/Badan Riset dan Inovasi Nasional. 


\section{DAFTAR PUSTAKA}

Abubakar, U.S., Yusuf, K.M., Safiyanu, I., Abdullahi, S., Saidu, S.R., Abdu, G.T. \& Indee, A.M. 2016. Proximate and mineral composition of corn cob, banana and plantain peels. International Journal of Food Science and Nutrition. 1(6), 25-27

Adisakwattana, S., Sompong, W., Meeprom, A., Ngamukote, S. \& Yibchok-anun, S. 2012. Cinnamic acid and its derivatives inhibit fructose-mediated protein glycation. International Journal and Molecules Science. 13, 1778-1789

Adom, K.K. \& Liu, R.H. 2002. Antioxidant activity of grains Journal of Agricultural and. Food Chemistry. 50(21), 6182-6187.

Alothman, M., Bhat, R. dan Karim, A.A. 2009. Antioxidant capacity and phenolic content of selected tropical fruits from Malaysia, extracted with different solvents. Food Chemistry. 115(3), 785788.

Ames, B.N. \& Shigenaga. M.K. 1993. Oxidants are a major contributor in cancer and aging. Dalam B. Haliwell and O.I. Aruoma (Eds). DNA and Free Radicals, Ellis Horwoosd Ltd., West Sussex, U.K.

Booth, A. A., Khalifah, R.G. \& Hudson, B.G. 1996. Thiamine pyrophosphate and pyridoxamine inhibit the formation of antigenic advanced glycation endproducts: comparison with aminoguanidine. Biochemical Biophysical Research Communications. 220, 113-119.

Dareda, C.T., Suryanto, E. \& Momuat, L.I. 2020. Karakterisasi dan aktivitas antioksidan serat pangan dari daging buah pala (Myristica fragrans Houtt). 13(1), 48-55.

Dvořáková, M, Guido, L.F., Dostálek, P., Skulilová, Z., Moreira, M.M \& Barros, A.A. 2008. Antioxidant Properties of Free, Soluble Ester and Insoluble-Bound Phenolic Compounds in Different Barley Varieties. Journal of Institute Brewing. 114(1), 27-33.

Ganeshan, S., Balasubramaniem, A. \& Perumal, V. 2015. Pholotannins from brown algae : inhibition of ages formation in high glucose induced Caenorhabditis elegans. Indian Journal of Experimental

Biology. 53(6), 371-379.

Gill, M.I., Tomas-Barberan, F.A., Hess-Pierce, B., Holcroft, D.M. dan Kader, A.A. 2000. Antioxidant activity of pomegranate juice and its relationship with phenolic composition and processing. Journal of Agricultural and Food Chemistry. 48(10), 4581-4589.

Halliwel, B. \& Gutteridge. J.M.C. 2001. "Free radicals in biology and medicine", Oxford University Press, London.

Hingse, S.S. , Digole, S.B. \& Annapure, U.S. 2014. Method development for simultaneous detection of ferulic acid and vanillin using high-performance thin layer chromatography. Journal of Analytical Science and Technology. 5(21), 1-9.

Jeong, S.M., Kim, S.Y., Kim, D.R., Jo, S.C., Nam, K.C. Ahn, D.U. \& Lee, S.C. 2004. "Effect of heat treatment on the antioxidant activity of extracts from citrus peels". Journal of Agricultural and. Food Chemistry. 52(11), 33893393.

Jime'nez-Escrig, A., Rincon, M., Pulido, R. \& Saura-Calixto, F. 2001. Guava fruit (Psidium guajava L.) as a new source of antioxidant dietary fiber. Journal of Agricultural and. Food Chemistry. 49(11), 5489-5493

Karamac,M., Kosiñska, A. \& Pegg, R.B. 2005. Comparison of radical-scavenging activities for selected phenolic acids. Polish Journal of Food and Nutrition Sciences. 55(2), 165-170.

Karepu, M.G., Suryanto, E. \& Momuat, I.M. 2020. komposisi kimia dan aktivitas antioksidan dari paring kelapa (Cocos nucifera). Chemistry Progress. 13(1): 39-47.

Krone, C.A. \& Ely, J.T. 2004. Ascorbic acid, glycation, glycohemoglobin and aging. Medical Hypotheses. 62(2), 275-279.

Li, X.C., Lin, J., Gao, Y., Han, W. \& Chen, D. 2012. Antioxidant ability and mechanism of rhizoma Atractylodes macrocephala. Molecules. 17(11), 13457-13472

Lunceford, N. \& Gugliucci, A. 2005 Ilex paraguariensis extracts inhibit AGE formation more efficiently than green tea. Fitoterapia. 76(5), 419- 427 
Mabry, T.J, Markham, K.R. \& Thomas, M.B. 1970. The systematic identification of flavonoids, Springer, New York, NY, USA

Macheix, J.J, Fleuriet, A. \& Billot, J. 990. Fruit Phenolics. CRC Press, Bota Raton, FL.

Mesquita, C.S., Oliveira, R., Bento, F., Geraldo, D., Rodrigues, J. \& Marcos, J.C. 2014. Simplified 2,4-dinitrophenylhydrazine spectrophotometric assay for quantification of carbonyls in oxidized proteins. Analytical Biochemistry.

Nova, Suryanto, E. \& Momuat, L.I. 2020. Karakterisasi fisikokimia dan aktivitas antioksidan serat pangan dari ampas empulur sagu baruk (Arenga microcarpha B.). 13(1), 22-29.

Parra, L.D.C., Saldivar, S.O.S. \& Liu, H.R. 2007. Effect of Processing on the Photochemical Profile and Antioxidant Activity of Corn for Production of Masa, Tortillas, and Tortilla Chips. Journal of Agicultural and Food Chemistry. 55(10), 4177-4183.

Peng, X. Zheng, Z, Cheng, K.W. Shan, F.G., Ren, X., Chen, F., \& Wang, M. 2008. Inhibitory effect of ${ }^{\text {mung }}$ been extract and it's constituent's vitexin and isovitexin on the formation of advanced glycation ends product. Food Chemistry. 106(2), 475-500.

Pérez-Jiménez, J. \& Torres, J.L. 2011. Analysis of nonextractable phenolic compounds in foods: the current state of the art. Journal of Agricultural and Food Chemistry. 59(24), 12713-12724.

Rahbar, S., Yerneni, K.K., Scott, S \& Gonzales, N. \& Lalezari, I. 2000. Novel Inhibitors of advanced glycation endproducts (Part II). Molecular Cell Biology Research Communications. 3(6), 360-366.

Saura-Calixto, F. 1998. Antioxidant dietary fiber product: a new concept and a potential food ingredient. Journal of Agricultural and. Food Chemistry. 46(10), 4303-4306

Shahidi, F. \& Naczk, M. 1995. Food Phenolics: sources, chemistry, effects and applications. Technomic Publication Company, Inc., Lancaster.

Su, D., Zhang, R., Hou, F., Zhang, M., Guo, J Huang, F., Deng, Y. \& Wei, Z. 2014. Comparison of the free and bound phenolic profiles and cellular antioxidant activities of litchi pulp extracts from different solvents. Complementary and Alternative Medicine, 14(9), 2-10.

Suryanto, E. L. I. Momuat, A. Yudistira \& F. Wehantouw. 2013. The evaluation of singlet oxygen quenching and sunscreen activity of corncob. Indonesian. $J$. Pharm. 24(2), 274-283

Suryanto, E. \& Momuat, L.I. 2017. Isolasi dan aktivitas antioksidan fraksi dari ekstrak tongkol jagung (Zea mays). AGRITECH. 37(2), 149-157

Suryanto, E. 2018. Kimia Antioksidan. Patra Media Grafindo, Bandung.

Suryanto, E., Momuat, L.I., Rotinsulu, H., \& Mewengkang, D.S. 2018. Antiphotooxidant and photoprotective activities of ethanol extract and solvent fractions from corn cob (Zea mays). Inter. J. ChemTech. Res. 11(3), 25-37

Suryanto, E. \& Taroreh, M.R.I. 2020. Ultrasound-assisted extraction antioksidan serat pangan dari tongkol jagung (Zea mays L.). Chemistry Progress. 12(2), 116-124.

Szydlowska-Czerniak, A., Dianoczki, C., Recseg, K., Karlovits, G. \& Szlyk, E. 2008. Determination of antioxidant capacities of vegetable oils by ferric-ion spectrophotometric methods. Talanta. 76(4), 899-905.

Tao, B., Ye, F., Li, H., Hu, Q., Xue, S. \& Zhao, G. 2014. Phenolic profile and in vitro antioxidant capacity of insoluble dietary fiber powders from Citrus (Citrus junos sieb. ex Tanaka) pomace as affected by ultrafine grinding. Journal of Agricultural and. Food Chemistry. 62(29), 7166-7173.

Trinidad, T.P., Valdez, D., Mallillin, A.C., Askali, F.C., Maglaya, A.S., Chua, M.T., Castillo, J.C., Loyola, A.S. \& Masa, D.B. 2001. Coconut flour from residue: A good source of dietary fiber. Indian Coconut Journal. 7, 309-17.

Vinson, J.A. \& Howard, III.T.B. 1996. Inhibition of protein glycation and advanced glycation end products by ascorbic acid and other vitamins and nutrients. Journal of Nutrttion Biochemistry. 7(12), 659-663.

Waworuntu, M.G., Suryanto, E. \& Momuat, I.M. 2018. Aktivitas penangkal radikal bebas dan penstabil oksigen singlet dari ekstrak biji jagung manado kuning (Zea 
mays L). Chemistry Progress. 11(1), 35-

41.

Wu, C-H \& Yen, G-C. 2005. Inhibitory Effect of Naturally Occurring Flavonoids on the Formation of Advanced Glycation Endproducts. Journal of Agricultural and. Food Chemistry. 53(8), 3167-3173

Yamaguchi, F., Ariga, T., Yoshimura, Y. \& Nakazawa, H. 2000. Antioxidative and Anti-Glycation Activity of Garcinol from Garcinia indica Fruit Rind. Journal of Agricultural and. Food Chemistry, 48(2), 180-185.

Yang, L., Zhang, H., Cheng, L., Gu, Z., Hua, D., Qi, X., Qian, H. \& Wang. L. 2014. Effect of extrusion on the hydrophilic antioxidant capacity of four whole grains. Journal of Food and Nutrition Research. 2(2), 80-87.

Yang, X-J., Dang, B. \& Fan, M-T. 2018. Free and Bound Phenolic Compound Content and Antioxidant Activity of Different Cultivated Blue Highland Barley Varieties from the Qinghai-Tibet Plateau. Molecules. 23(879), 2-20. 